\title{
SIXTH DEGREE OF FREEDOM
}

\author{
Alexander S. Gorodetsky ${ }^{1}$, Maryna A. Romashkina ${ }^{1}$, Bogdan Yu. Pisarevsky ${ }^{1,2}$ \\ ${ }^{1}$ LLC "LIRA CAD", Kiev, UKRAINE \\ ${ }^{2}$ National Aviation University, Kiev, UKRAINE
}

\begin{abstract}
The article describes new types of finite elements that allow you to take into account all six degrees of freedom of the shell. In order to compose the finite elements, the Allman functional with a rotational degree of freedom is used. The use of finite elements is associated with a number of restrictions that are considered in the article.
\end{abstract}

Keywords: flat shell, method of smoothing deformations, rotational degrees of freedom

\section{ШЕСТАЯ СТЕПЕНЬ СВОБОДЫ}

\author{
А.С. Городецкий ${ }^{1}$, М.А. Ромашкина ${ }^{1}$, Б.Ю. Писаревский ${ }^{1,2}$ \\ ${ }^{1}$ ООО «ЛИРА САПР», г. Киев, УКРАИНА \\ ${ }^{2}$ Национальный авиационный университет, г. Киев, УКРАИНА
}

\begin{abstract}
Аннотация: В статье описаны новые типы конечных элементов, которые позволяют учитывать все шесть степени свободы оболочки. Для составления конечных элементов используется функционал Аллмана с вращательной степенью свободы. Применение конечных элементов связано с рядом ограничений, которые рассмотрены в статье.
\end{abstract}

Ключевые слова: плоская оболочка, метод сглаживания деформаций, вращательная степени свободы

Structural analysis of spatial core systems, as a rule, implies that there are six movements (according to the finite element approach, these are six degrees of freedom) and six corresponding efforts in each node. Each degree of freedom has a physical meaning: linear movements in the direction of the axes $\mathrm{X}, \mathrm{Y}, \mathrm{Z}$ and an angle of rotation $\mathrm{UX}, \mathrm{UY}, \mathrm{UZ}$ relative to the same axes. When calculating plate systems, the physical meaning of the rotation angle UZ (sixth degree of freedom) relative to the axis of the orthogonal plane of the plate (Fig. 1) is an abstraction.

The history of the finite element method contains examples of various exotic degrees of freedom of type

$$
\frac{\partial^{2} u_{z}}{\partial x^{2}} ; \frac{\partial^{2} u_{z}}{\partial x \partial y}
$$

etc. However, all of them sooner or later showed their failure. For example, the degree of freedom of the type

$$
\frac{\partial^{2} u_{z}}{\partial x^{2}} ; \frac{\partial^{2} u_{z}}{\partial x \partial y}
$$

and other higher derivatives of displacements when changing the orientation of the global coordinate system (a necessary procedure for universal computational complexes) give rise to other types and degrees of freedom.

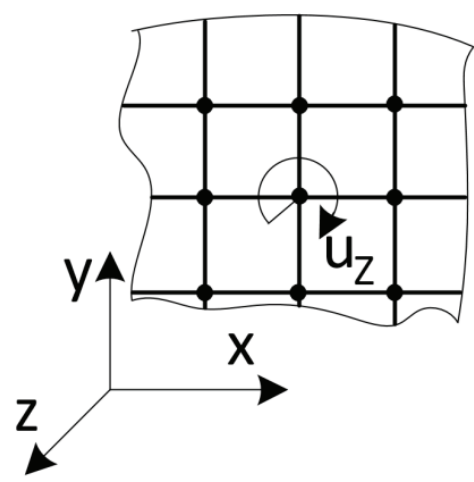

Figure 1. Sixth degree of freedom in the FE shell. 
Quadrilateral finite element with a rotating degree of freedom

In various publications, the construction of a stiffness matrix is given. So in [4], the finite element is obtained as a result of combining the approximating Allman functions (moving in the plane of the finite element) and the bilinear normal rotation functions (rotating displacements) [8] (Fig. 2).

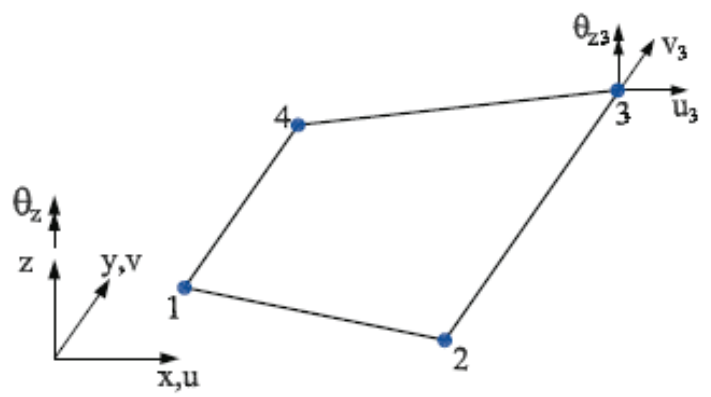

Figure 2. Quadrilateral finite element with a rotating degree of freedom

The field of rotating movements is interpolated as follows:

$$
\theta_{z}=\sum_{i=1}^{4} N_{i}(\xi, \eta) \theta_{z i}
$$

Field of displacements in the plane:

$\mathrm{u}=\left\lfloor\begin{array}{l}u \\ v\end{array}\right\rfloor=\sum_{i=1}^{4} N_{i}\left\lfloor\begin{array}{l}u_{i} \\ v_{i}\end{array}\right\rfloor+\frac{1}{8} \sum_{k=5}^{8} N_{k}(\xi, \eta)\left(\theta_{z j}-\theta_{z i}\right)\left\lfloor\begin{array}{l}y_{i j} \\ x_{i j}\end{array}\right\rfloor$,

where

$$
\begin{array}{cc}
x_{i j}=x_{j}-x_{i}, \quad y_{i j}=y_{j}-x_{i}, & \\
N_{i}(\xi, \eta)=\frac{1}{4}\left(1+\xi_{i} \xi\right)\left(1+\eta_{i} \eta\right) & \mathrm{i}=1,2,3 \\
N_{k}(\xi, \eta)=\frac{1}{2}\left(1-\xi^{2}\right)\left(1+\eta_{k} \eta\right) & \mathrm{k}=5,7 \\
N_{k}(\xi, \eta)=\frac{1}{2}\left(1+\xi_{k} \xi\right)\left(1-\eta^{2}\right) & \mathrm{k}=6,8 .
\end{array}
$$

where $\mathrm{k}, \mathrm{i}, \mathrm{j}$ is determined as $(5,1,2),(6,2,3)$, $(7,3,4),(8,4,1)$.
Matrix of deformation $\varepsilon_{m}$ is determined as

$$
\begin{array}{r}
\varepsilon_{m}=\sum_{i=1}^{4} B_{m i} u_{i}, \\
\mathrm{u}_{\mathrm{i}}=\left[\begin{array}{lll}
u_{i} & v_{i} & \theta_{i}
\end{array}\right]^{T}
\end{array}
$$

where

is nodal displacement vector.

Matrix of derivatives $B_{m i}$ has a form:

$$
B_{m i}=\left\lfloor\begin{array}{ccc}
N_{i, x} & 0 & N x_{i, x} \\
0 & N_{i, y} & N y_{i, y} \\
N_{i, y} & N_{i, x} & N x_{i, x}+N y_{i, y}
\end{array}\right\rfloor,
$$

Where $N x, N y$ incompatible form functions defined as:

$$
\begin{aligned}
& N x_{i}=\frac{1}{8}\left(y_{i j} N_{l}-y_{i k} N_{m}\right), \\
& N y_{i}=\frac{1}{8}\left(x_{i j} N_{l}-x_{i k} N_{m}\right),
\end{aligned}
$$

Indexes i, j, k, m take values:

$\mathrm{i}=1,2,3,4 ; \mathrm{m}=\mathrm{i}+4 ; 1=\mathrm{m}-1+4$ floor $(1 / \mathrm{i})$;

$\mathrm{k}=\bmod (\mathrm{m}, 4)+1 ; \mathrm{j}=1-4$;

matrix of deformation $\left(\varepsilon_{\mathrm{sk}}\right)$ is expressed in the form

$$
\varepsilon_{s k}=\sum_{i=1}^{4} b_{i} u_{i}+\theta_{z},
$$

where

$$
b_{i}=\left[\begin{array}{c}
-\frac{1}{2} N_{i, y} \\
\frac{1}{2} N_{i, x} \\
\frac{1}{16}\left(-y_{i j} N_{l, y}+y_{i k} N_{m, y}+x_{i j} N_{l, x}-x_{i k} N_{m, x}\right)-N_{i}
\end{array}\right],
$$


Indexes $\mathrm{i}, \mathrm{j}, \mathrm{k}, \mathrm{m}$ is determined by expression presented above.

The variational formulation of the finite element method proposed in [6] is defined as:

$$
\Pi_{\gamma}\left(\mathrm{u}, \theta_{z}\right)=\frac{1}{2} \int_{\Omega} \varepsilon_{m}^{T} D_{m} \varepsilon_{m} d \Omega+\frac{1}{2} \gamma \int_{\Omega}\left(\varepsilon_{s k}-\theta_{z}\right)^{2} d \Omega-\int_{\Omega} \mathrm{u}^{\mathrm{T}} \mathrm{f} d \Omega,
$$

The resulting stiffness matrix is $K_{m e m}$ sum of matrix $K_{m}$ and penalty matrix $P_{\gamma}$.

$$
K_{m e m}=K_{m}+P_{\gamma}=\int_{\Omega} B_{m}^{T} D_{m} B_{m} d \Omega+\gamma \int_{\Omega} b^{T} b d \Omega .
$$

Positive penalty coefficient $\gamma$ in the equation is problematic issue. However, it is customary to equate the coefficient equal to the shear modulus $(\gamma=G)[7-8]$.

Apologists of the sixth degree of freedom usually give the notorious example of an "umbrella" - the task about the slab supported on a single column. In this case the slab is subjected to torsion relative to the vertical axis of the column.

If we simulate the support of the plate on a single point without a sixth degree of freedom in the assembly, then there will be no clamping of the plate in the column, and the plate will rotate relative to the column. We solve this problem taking into account the sixth degree of freedom in the shell.

Example 1 - The use of the sixth degree of freedom in structures of the type "umbrella" Initial data: square plate $\mathrm{a}=6 \mathrm{~m}$, rigidly complied with a column of square cross-section $0.5 \times 0.5 \mathrm{~m}$; length $1=6 \mathrm{~m}$. Plated is under the action of an axial force $\mathrm{p}=1 \mathrm{t}$.

Material characteristic: $E=3 \times 10^{6} \mathrm{t} / \mathrm{m}^{2} ; \quad v=0.2$. Boundary conditions: the column at the base is rigidly clamped. Figure 3 shows calculation scheme of such a construction.

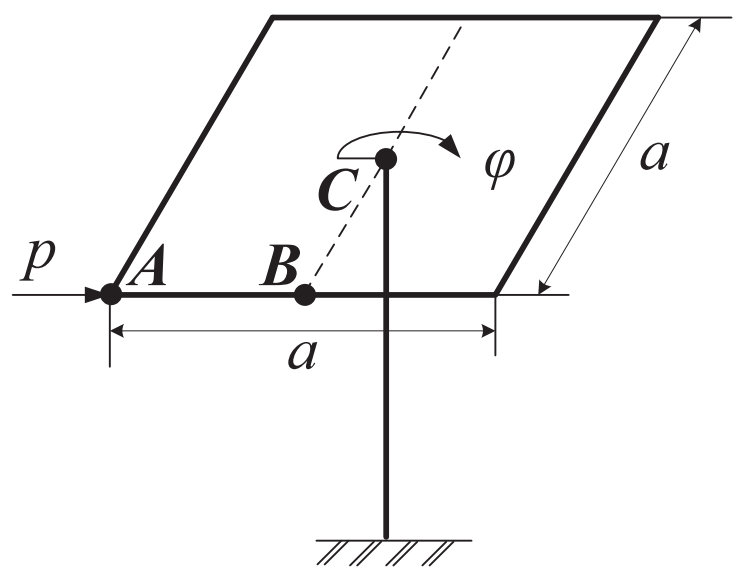

Figure 3. The calculation scheme of the plate supported on a single

Solution:

$$
\begin{aligned}
& x_{m . B}=x_{m \cdot C}+u z_{m \cdot C} \cdot \frac{a}{2}= \\
& =4.608+1.646 \cdot 10^{-3} \cdot 3000=9.546(\mathrm{MM})
\end{aligned}
$$

Figure 4 and table 1 shows results of structural analysis of structures of the type "umbrella", performed in Lira - CAD Software.

Analyzing the results given in Table 1, we can conclude that the thickening of the grid does not lead to a refinement of the solution, which indicates the incorrectness of the sixth degree of freedom. Similar problems, in a slightly different plane, are considered in [12].

It should be noted that modern modeling techniques include accounting for the "body" of the column. In this case, the interface node of the column and plate is calculated using absolutely rigid bodies (Fig. 5,6) and you can do without the sixth degree. Perfectly rigid body (PRT) provides a kinematic connection between the movements of the driven nodes and the leading ones. The LIRA-CAD Software allows introducing such rigid bodies automatically. The introduced rigid bodies can simulate the "body" of a column of any configuration (cross, corner, $\mathrm{T}$, etc.). The LIRA-CAD Software allows corresponding between a single master node and an arbitrary number of slave nodes. 
Load 1

Mosaic plot of displacement along the $\mathrm{X}$-axis (in global system)

Units of measurement - $\mathrm{mm}$
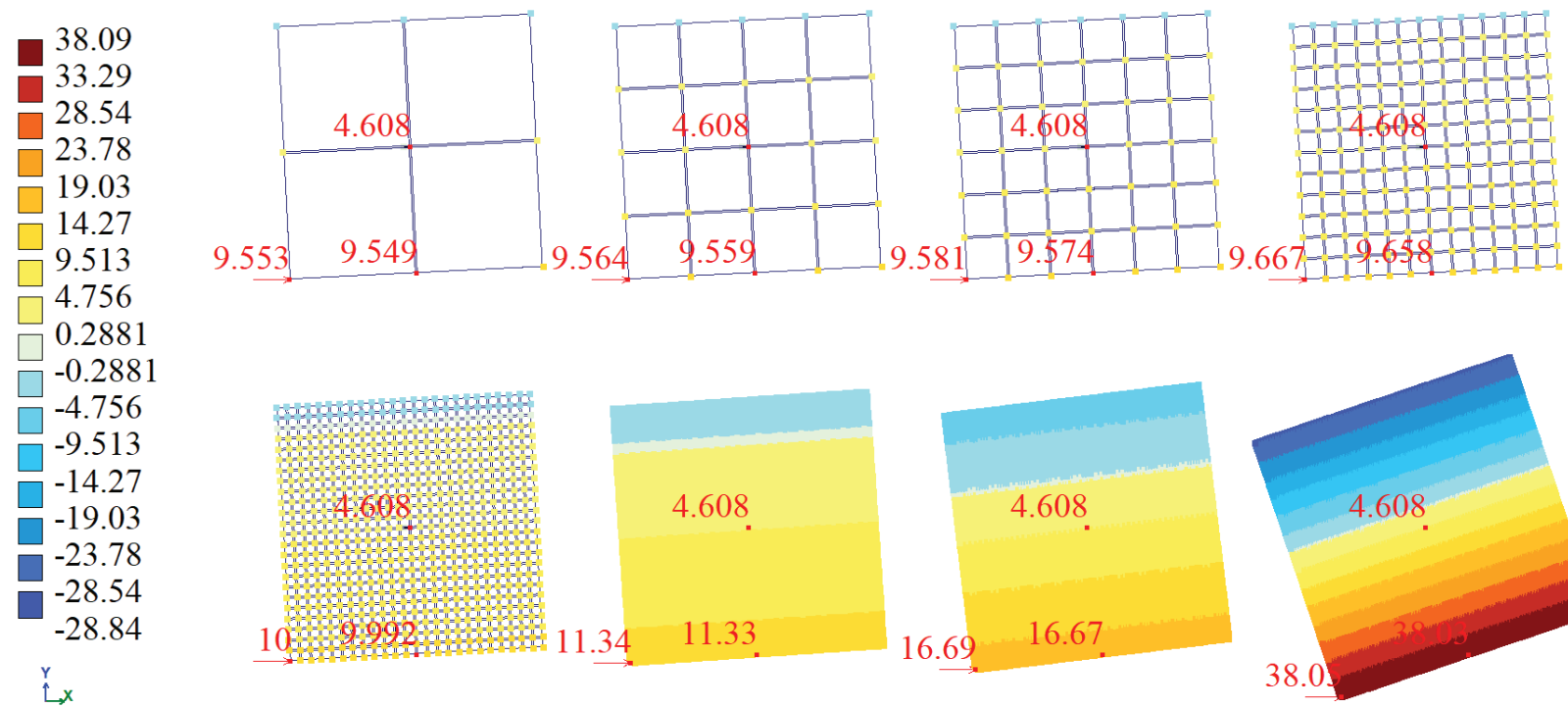

4.756

0.2881

$-0.2881$

$-4.756$

$-9.513$

$-14.27$

$-19.03$

$-23.78$

$-28.54$

Y.X
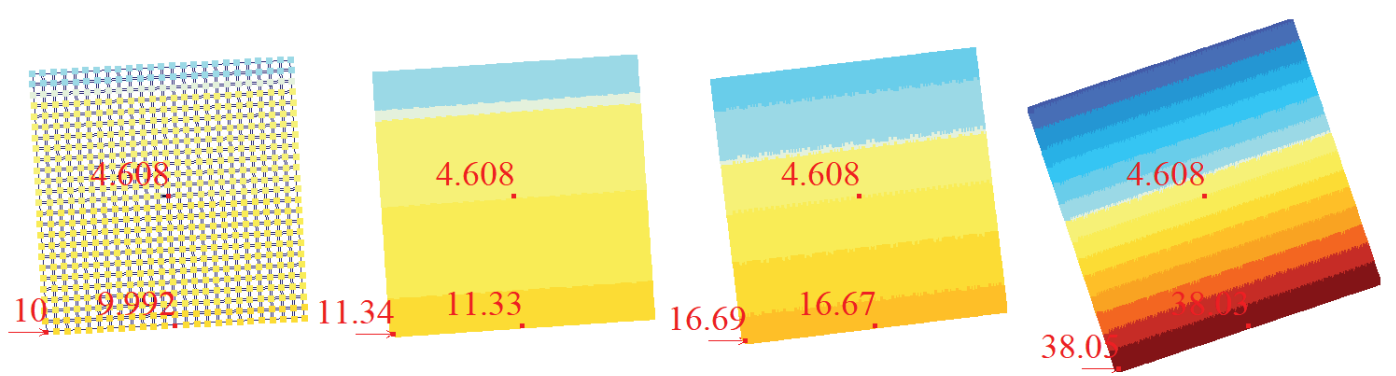

Figure 4. Displacements along the X axis, $m m$ at the control point for various mesh densities (taking into account the sixth degree of freedom in the shell)

Table 1. Results of structural analysis of structures of the type "umbrella"

\begin{tabular}{|c|c|c|c|}
\hline & $\begin{array}{c}\text { Displacements in the } \\
\text { point B along the axis } \\
\mathrm{x}, \mathrm{mm} \text { (an analytical } \\
\text { solution) }\end{array}$ & $\begin{array}{l}\text { Displacements in the } \\
\text { point B along the axis } \\
\mathrm{x}, \mathrm{mm} \text { (Lira - CAD } \\
\text { Software) }\end{array}$ & Error, \% \\
\hline $2 \times 2$ & 9.546 & 9.549 & 0.031 \\
\hline $4 \times 4$ & 9.546 & 9.559 & 0.136 \\
\hline $6 \times 6$ & 9.546 & 9.574 & 0.292 \\
\hline $12 \times 12$ & 9.546 & 9.658 & 1.160 \\
\hline $24 \times 24$ & 9.546 & 9.992 & 4.464 \\
\hline $48 \times 48$ & 9.546 & 11.33 & 15.746 \\
\hline $96 \times 96$ & 9.546 & 16.67 & 42.735 \\
\hline $192 \times 192$ & 9.546 & 38.03 & 74.899 \\
\hline
\end{tabular}

This modeling method, on the one hand, solves the problem of accounting for the "body" of the column, i.e. "Cut-offs" of the peak of moments arising when modeling the support on the column as a point support. On the other hand, it provides the perception of the column of twisting deformations. In most cases, when there are at least two columns, this is not required, because in this case, the torque from deformations in the plane of the plate will be perceived by pairs of transverse forces in the columns, and the torques will be negligibly small and their presence can simply be ignored (the effect of neglecting the moments in the constructed rigid nodes of the trusses when the hinged nodes were taken into account) [1].

This modeling method, on the one hand, solves the problem of accounting for the "body" of the column, i.e. "Cut-offs" of the peak of moments arising when modeling the support on the column as a point support. On the other hand, it provides the perception of the column of twisting deformations. 


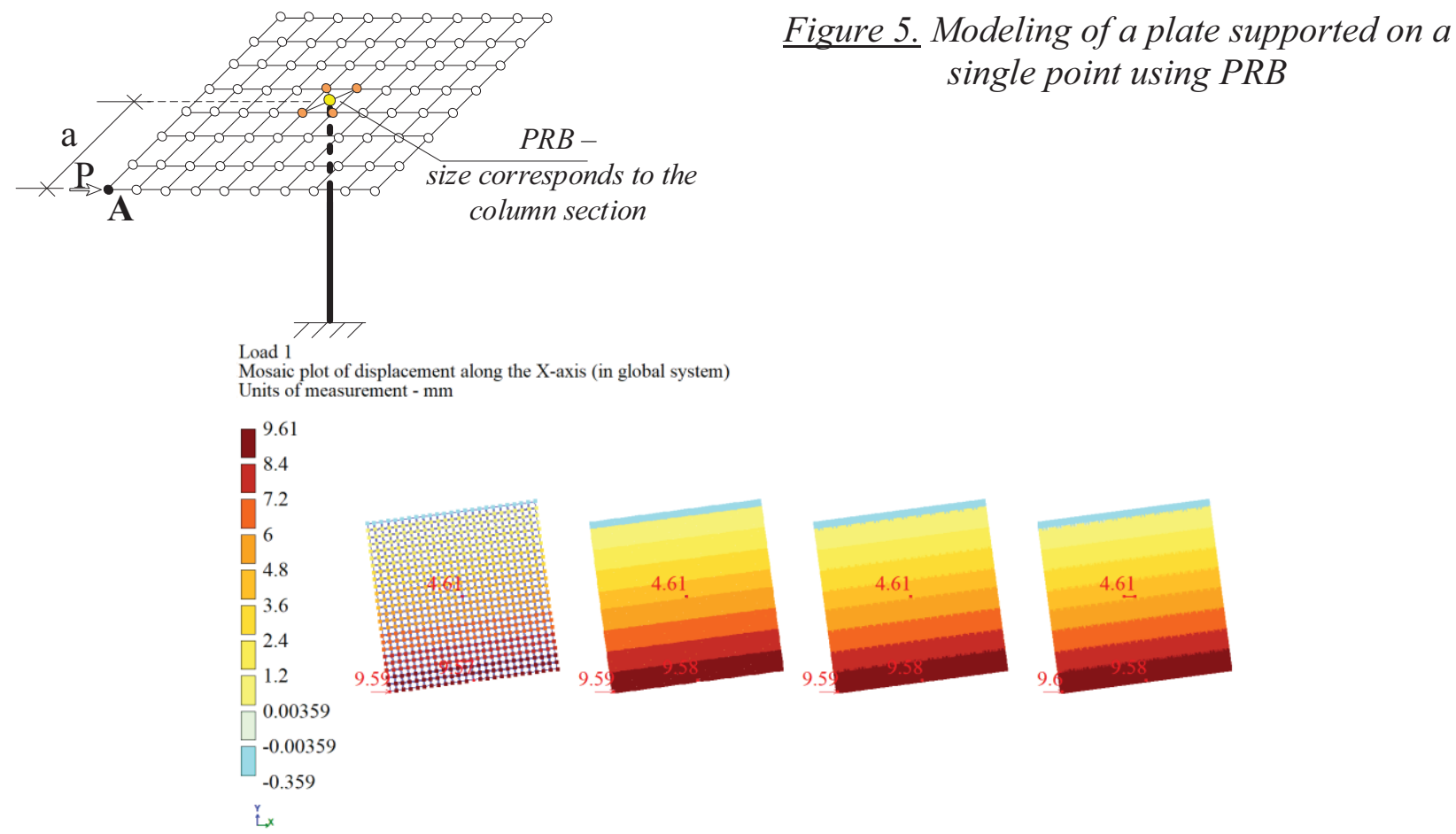

Figure 6. Displacements along the $X$ axis, $m$ m at the control point for different mesh densities (the node linking column and plate calculated using PRB)

In most cases, when there are at least two columns, this is not required, because in this case, the torque from deformations in the plane of the plate will be perceived by pairs of transverse forces in the columns, and the torques will be negligibly small and their presence can simply be ignored (the effect of neglecting the moments in the constructed rigid nodes of the trusses when the hinged nodes were taken into account) [1].

\section{Example 2 - The use of the sixth degree of} freedom in structures such as "folded shell" Somebodies call various spatial plate systems as a reason to apply the sixth degree of freedom (Fig. 7).

Each node of a spatial structure of this type has six degrees of freedom (three linear and three angular displacements). As a rule, the node of the finite element of a flat plate has five degrees of freedom. This causes the appearance of linearly dependent equations in the canonical system, i.e. division by zero in the process of eliminating unknowns.

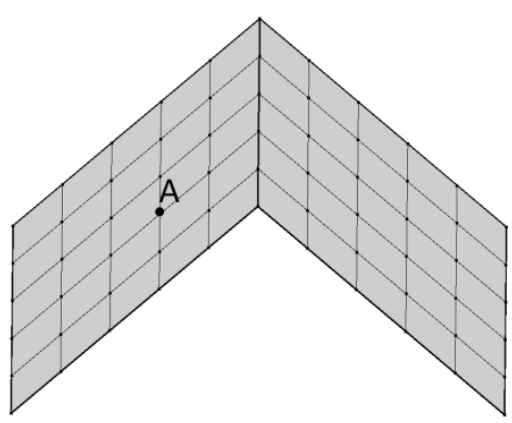

Figure 7. Using the sixth degree of freedom in a node when modeling spatial plate systems

Using the sixth degree of freedom, in some cases, solves this problem. Although advanced software systems have a procedure that circumvents this problem [2]. If during the process of elimination 0 appears in the diagonal canonical equations, then a connection is imposed in this direction at the absence of load in this direction. This simple procedure can be useful in many other cases [2, $10]$.

Nevertheless, in some cases, the sixth degree in the hands of inexperienced users can lead to incorrect results. 
Example 3 - Connection of the frame rod with the diaphragm

Figure 8 shows an example of modeling the girder clamped in a wall. Here the difficulties are due to the fact that the finite elements of the beam-walls (plane stress state) do not have nodal unknowns corresponding to the angle of rotation about an axis orthogonal to the plane of the diaphragm. Therefore, the node at point A (Fig. 8) without any additional measures will be hinged for the rod.
Modeling clamping with the sixth degree of freedom leads to incorrect results. When the mesh thickens, the moment in clamping decreases, i.e. the result substantially depends on the finite element grid, which is wrong.

Consider following example. We study the bending moment in the beam under the action of a concentrated vertical force $\mathrm{p}=1 \mathrm{t}$ at different mesh densities. Figure 8 shows such a calculation scheme. Figure 9 and Table 2 present the calculation results obtained in LIRA-CAD Software.

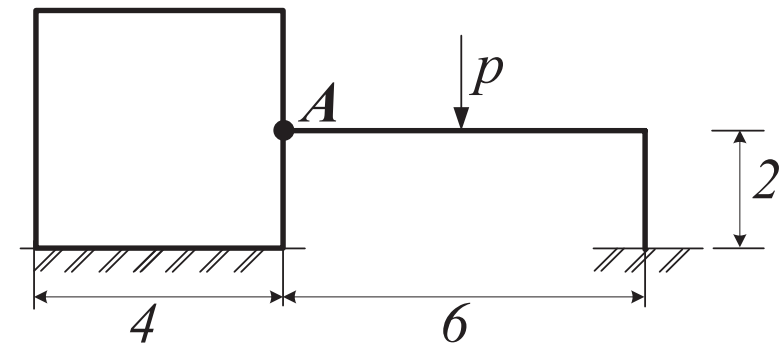

Figure 8. The design scheme of the frame (clamping of the girder in the wall)

Load 1
Diagram My
Units of measurement $-t * m$
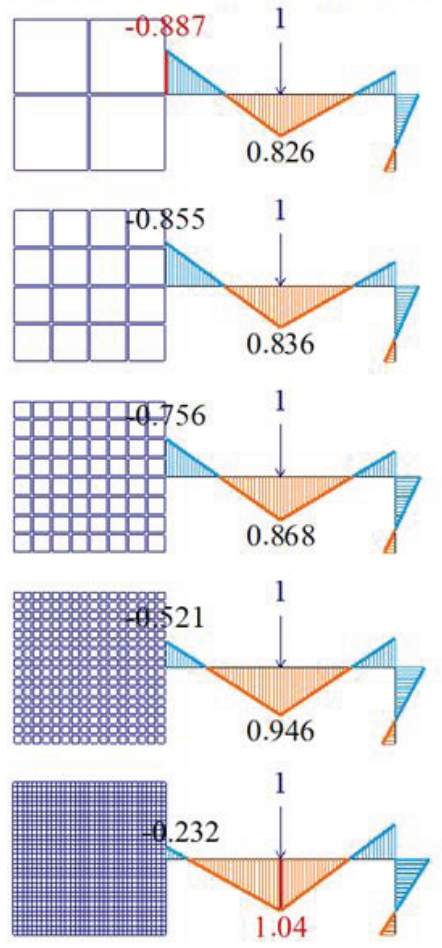

a)
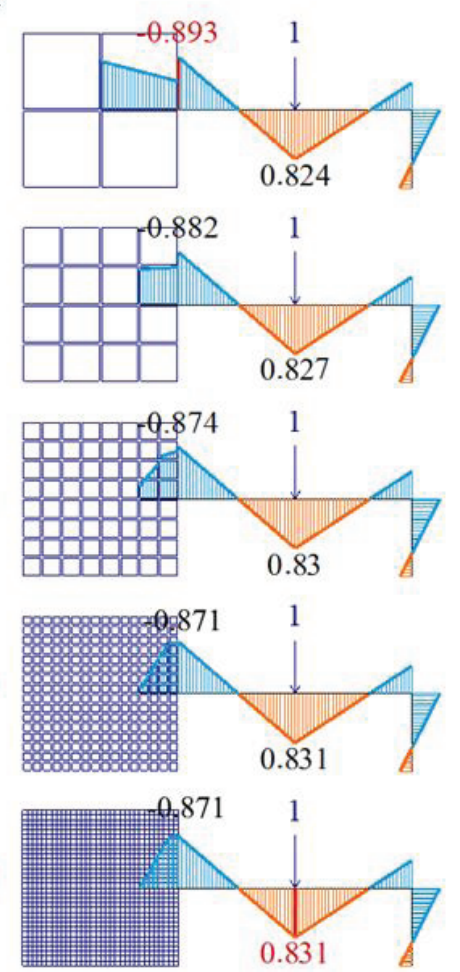

b)

Figure 9. Bending moment My, $t * m$ for various mesh densities: a) six degrees of freedom in the FE of the shell; b) the girder is inserted into the body of the wall 
Table 2. Bending moment My, $t * m$ at various mesh densities

\begin{tabular}{|c|c|c|}
\hline Finite element mesh & $\begin{array}{c}\text { My, } \mathrm{t} * \mathrm{~m} \text { (six degrees of } \\
\text { freedom in the FE of the } \\
\text { shell) }\end{array}$ & $\begin{array}{c}\text { My, } \mathrm{t} * \mathrm{~m} \text { (the girder is } \\
\text { inserted into the body of the } \\
\text { wall) }\end{array}$ \\
\hline $2 \times 2$ & -0.887 & -0.893 \\
\hline $4 \times 4$ & -0.855 & -0.882 \\
\hline $8 \times 8$ & -0.756 & -0.874 \\
\hline $16 \times 16$ & -0.521 & -0.871 \\
\hline $32 \times 32$ & -0.232 & -0.884 \\
\hline
\end{tabular}

In this case, clamping must be modeled in other ways (introducing PRB, introducing a girder into the wall body, etc.) [5]. In order to provide clamping of the frame rod in the diaphragm body, it is possible to recommend the introduction of an additional rod between nodes A and B (Fig. 9 b,
10). On the one hand, the extention of such a rod will introduce some local perturbations, but, on the other hand, in a number of cases it will simulate the constructive solution of the assembly (installation of reinforcement of an adjacent rod for the purpose of anchoring) [1].
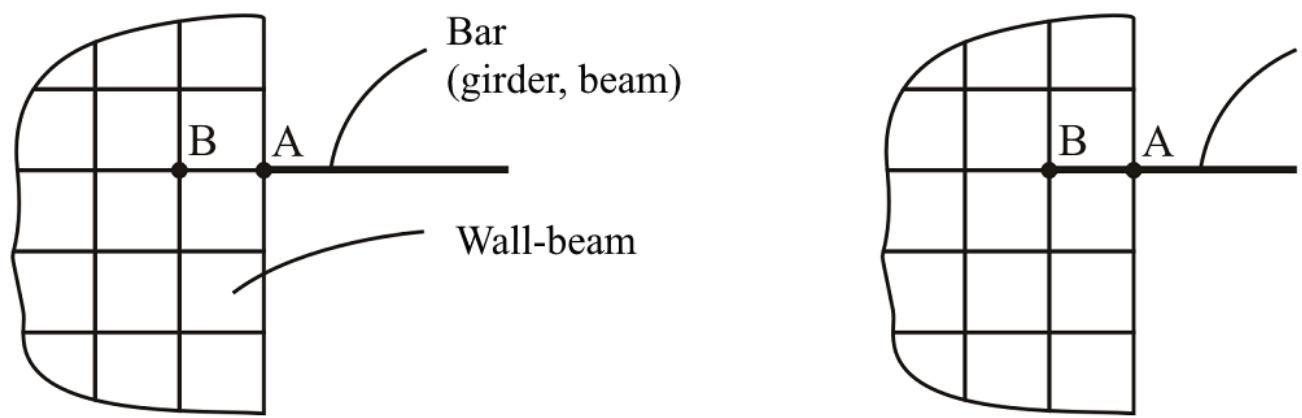

Bar is extended up to node $\mathrm{B}$

Figure 10. Simulation of the connection of the frame rod with the diaphragm (the girder is inserted into the body of the wall)

An another way is to introduce the Perfectly Rigid Body (PBR) at the point where the beam adjoins the diaphragm (the height of the PRB should be equal to the height of the beam, the leading unit is located at the center of gravity of the beam section) (Fig. 11). This will provide a kinematic connection between the nodes of the diaphragm and the beam [11].

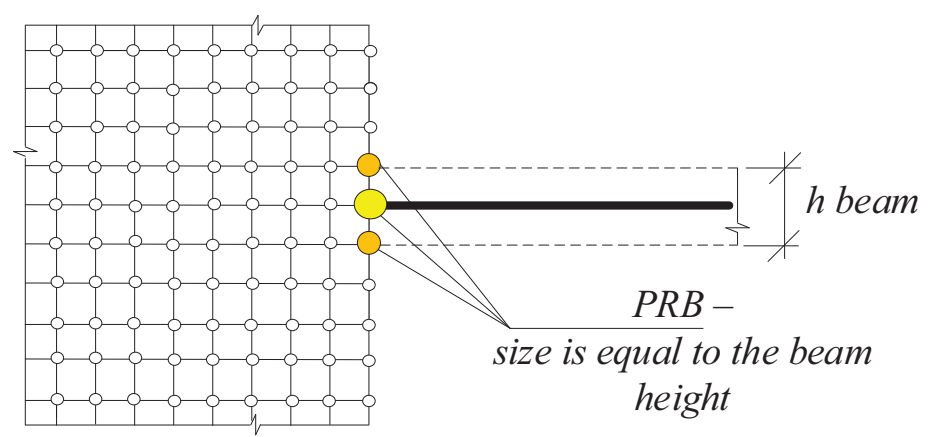

Figure 11. Simulation of the connection of the frame rod with the diaphragm using PRB 
As a rule, the number of degrees of freedom exceeds the accuracy of the solution. With the

Example 3 - a rectangular beam-wall, rigidly suspended on the sides, under the action of a uniformly distributed load located on the upper side.

Consider the problem (Fig. 12), which has an exact solution [3].

Initial data:

Load: uniformly distributed load acting in the plane of the beam-wall along the $Z$ axis: $p=500$ $\mathrm{N} / \mathrm{m}$. Dimensions: $\mathrm{h}=0.1 \mathrm{~m} ; \mathrm{b}=1.6 \mathrm{~m} ; \mathrm{a}=1.6$ m. Material characteristic: $\mathrm{E}=2.65 \times 106 \mathrm{~Pa} ; \mathrm{v}=$ 0.15 . Boundary conditions: rigidly suspended on the sides. Fig. 12 shows the design scheme of the beam-wall. sixth degree of freedom, the situation is somewhat different.

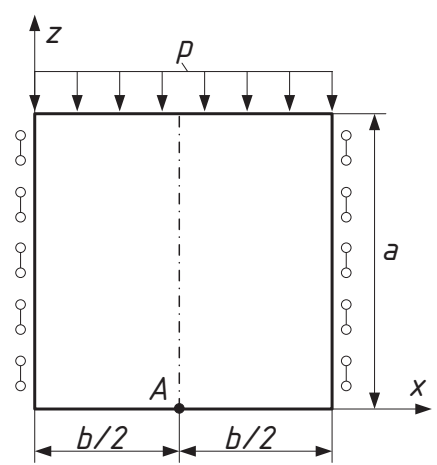

Figure 12. The design scheme of the beam-wall

The task:

Determine the displacements in node A along the $\mathrm{Z}$ axis for the finite elements of the beam-wall at different mesh densities and compare with the exact solution (Table 3 ).

Table 3. Comparison of the results of the calculation of the beam-wall, in the LIRA-CAD Software and analytical calculation

\begin{tabular}{|c|c|c|c|c|c|}
\hline \multirow[t]{2}{*}{ Type of FE } & \multirow[b]{2}{*}{ FE mesh } & \multicolumn{3}{|c|}{ displacements in node $\mathrm{A}$ along the $\mathrm{Z}$ axis, $\mathrm{m}^{*} 10^{-3}$} & \multirow{2}{*}{$\begin{array}{l}\text { A number of } \\
\text { unknown } \\
\text { parameters }\end{array}$} \\
\hline & & $\begin{array}{l}\text { Analytical } \\
\text { solution }\end{array}$ & $\begin{array}{l}\text { Numerical } \\
\text { solution (Lira- } \\
\text { CAD Software) }\end{array}$ & Error, \% & \\
\hline \multirow{4}{*}{$\begin{array}{l}\text { 1) FE21 (2 } \\
\text { freedom } \\
\text { degree per } \\
\text { node) }\end{array}$} & $2 \times 4$ & -0.95 & -0.786 & 17.26 & 20 \\
\hline & $4 \times 8$ & -0.95 & -0.905 & 4.74 & 72 \\
\hline & $8 \times 16$ & -0.95 & -0.939 & 1.16 & 272 \\
\hline & $16 \times 32$ & -0.95 & -0.947 & 0.32 & 1056 \\
\hline \multirow{4}{*}{$\begin{array}{l}\text { 2) FE28- } \\
\text { with } \\
\text { intermediate } \\
\text { nodes on } \\
\text { the sides }\end{array}$} & $2 \times 4$ & -0.95 & -0.947 & 0.32 & 56 \\
\hline & $4 \times 8$ & -0.95 & -0.95 & 0.00 & 208 \\
\hline & $8 \times 16$ & -0.95 & -0.95 & 0.00 & 800 \\
\hline & $16 \times 32$ & -0.95 & -0.95 & 0.00 & 3136 \\
\hline \multirow{4}{*}{$\begin{array}{l}\text { 3) FE21(3 } \\
\text { freedom } \\
\text { degree per } \\
\text { node) }\end{array}$} & $2 \times 4$ & -0.95 & -0.687 & 27.68 & 35 \\
\hline & $4 \times 8$ & -0.95 & -0.854 & 10.11 & 117 \\
\hline & $8 \times 16$ & -0.95 & -0.921 & 3.05 & 425 \\
\hline & $16 \times 32$ & -0.95 & -0.942 & 0.84 & 1617 \\
\hline
\end{tabular}


The Table 3 shows the value of the displacement along the $\mathrm{Z}$ axis per node $\mathrm{A}$ for different FE cells with different types of finite elements of the plane problem: 1) FE 21 with two degrees of freedom per node $(\mathrm{X}, \mathrm{Z})$; 2) KE 28 - a rectangular $\mathrm{KE}$ of a flat task (beam-wall) with intermediate nodes on the sides, with two degrees of freedom per node $(\mathrm{X}, \mathrm{Z})$; 3) KE 21 with three degrees of freedom per node (X, $\mathrm{Z}$ and the presence of the sixth degree of freedom UY).

Analyzing the results given in Table 3, it can be noted that the introduction of the sixth degree of freedom does not improve the accuracy of the solution, although the number of degrees of freedom increases. It should also be borne in mind that with an increase in the total number of unknowns L, the conditionality of the matrix $\mathrm{K}$ deteriorates, and this can lead to the inability to achieve a given accuracy, although the approximation order for the types of elements used can determine this accuracy. The conditional criterion for matrix $\mathrm{K}$ can be the spectral condition number a $(\mathrm{K})$. The greater a (K) corresponds to the worse the conditioning. The work [9] gives an estimate of a (K), which has the form at a uniform grid:

$$
a(K)=h^{-2 m}
$$

where $m$ is the order of the system of equations; $h$ is the maximum size of the finite elements.

It can be seen from estimate (2) that in concrete calculations of large problems it is better to avoid excessively dense computational grids, and to achieve the specified accuracy due to a higher approximation order.

\section{CONCLUSIONS}

1. In some cases (Fig. 3, 7) the introduction of the sixth degree of freedom makes some sense. Although in this case, the introduction of certain methods of adequate modeling avoids the need to use the sixth degree of freedom.
2. When modeling structural solutions of слампинг (Fig. 8), the application of the sixth degree of freedom leads to incorrect results.

3. The use of the sixth degree of freedom to improve the accuracy of solving the problem (Fig. 12) leads to the opposite results: the total number of degrees of freedom increases, and the accuracy deteriorates.

\section{REFERENCES}

1. Gorodetsky A., Barabash M., Sidorov V. Komp'juternoe modelirovanie v zadachah stroitel'noj mehaniki [Computer simulation in problems of structural mechanics]. Moscow, ASV Publishing House, 2016, 338 pages (in Russian).

2. Gorodetsky A.S, Evzerov I.D. Komp'juternye modeli konstrukcij [Computer models of the structures]. The Second Edition. Kiev, "FAKT", 2007, 394 pages (in Russian).

3. Kalmanok A.S. Raschet plastinok [Analysis of wall-beams]. Moscow, Gosstrojizdat, 1959, 212 pages (in Russian).

4. Allman D.J. A compatible triangular element including vertex rotations for plane elasticity analysis. // Computers and Structures, 1984, Volume 19, pp. 1-8.

5. Gorodetsky A.S., Batrak L.G., Gorodetsky D.A., Laznuk M.V., Yusipenko S.V. Raschet i proektirovanie konstrukcij vysotnyh zdanij iz monolitnogo zhelezobetona: problemy, opyt, vozmozhnye reshenija i rekomendacii, komp'juternye modeli, informacionnye tehnologii [Analysis and design of high-rise buildings from monolithic RC: difficulties, experience, possible solutions and recommendations, computer models, information technologies]. Kiev, FAKT, 2004, 106 pages (in Russian).

6. Hughes T.J.R., Brezzi F. On drilling degrees of freedom. // Computer Methods in Applied Mechanics and Engineering, 1989, Volume 72, pp. 105-121. 
7. Hughes T.J.R., Brezzi F., Masud A., Harari I. Finite element with drilling degrees of freedom: Theory and numerical evaluations. // Proceedings of the fifth international symposium on numerical methods in engineering. Computational mechanics publications, Ashurst, U.K., 1989, pp. 3-17.

8. Ibrahimbegovic A., Taylor R.L., Wilson E.L. (1990): A robust quadrilateral membrane finite element with drilling degrees of freedom. International Journal for Numerical Methods in Engineering, vol. 30, pp. 445-457.

9. Rozin L.A. Metod konechnyh jelementov v primenenii $\mathrm{k}$ uprugim sistemam [Finite element method applied to elastic systems]. Moscow, Stroyizdat, 1977, 129 pages (in Russian).

10. Barabash M.S. Komp'juternoe modelirovanie processov zhiznennogo cikla objektov stroitel'stva [Computer simulation of life cycle for the building objects]. Kiev, Steel, 2014, 301 pages (in Russian).

11. Kirjyazjev P., Genzersky Y., Romashkina M. Komp'juternye modeli uzlov primykanija $\mathrm{k}$ diafragme [Computer models for joints of slab-to-diaphragm connection]. // Scientific and technical collection: Issues of urban development. Kiev, NAU, 2014, No. 2 (12), pp. 236-246 (in Ukrainian).

12. Perelmuter A.V., Slivker V.I. Raschetnye modeli sooruzhenij i vozmozhnost' ih analiza [Design models of structures and the possibility of their analysis]. Kiev, Steel, 2002, 600 pages (in Russian).

\section{СПИСОК ЛИТЕРАТУРЫ}

\section{1. Городецкий А.С., Барабаш М.С., Сидоров В.Н. Компьютерное} моделирование в задачах строительной механики. - М.: АСB, 2016. - 338 с.

2. Городецкий А.С., Евзеров И.Д. Компьютерные модели конструкций. Киев: Факт, 2007. - 394 с.
3. Калманок А.С. Расчет пластинок. - М.: Госстройиздат, 1959. - 212 с.

4. Allman D.J. A compatible triangular element including vertex rotations for plane elasticity analysis. // Computers and Structures, 1984, Volume 19, pp. 1-8.

5. Городецкий А.С., Батрак Л.Г., Городецкий Д.А., Лазнюк М.В., Юсипенко С.В. Расчет и проектирование конструкций высотных зданий из монолитного железобетона: проблемы, опыт, возможные решения и рекомендации, компьютерные модели, информационные технологии. - Киев: Факт, 2004. - 106 c.

6. Hughes T.J.R., Brezzi F. On drilling degrees of freedom. // Computer Methods in Applied Mechanics and Engineering, 1989, Volume 72, pp. 105-121.

7. Hughes T.J.R., Brezzi F., Masud A., Harari I. Finite element with drilling degrees of freedom: Theory and numerical evaluations. // Proceedings of the fifth international symposium on numerical methods in engineering. Computational mechanics publications, Ashurst, U.K., 1989, pp. 3-17.

8. Ibrahimbegovic A., Taylor R.L., Wilson E.L. A robust quadrilateral membrane finite element with drilling degrees of freedom. // International Journal for Numerical Methods in Engineering, 1990, Volume 30, pp. 445457.

9. Розин Л.А. Метод конечных элементов в применении к упругим системам. - М.: Стройиздат, 1977. - 129 с.

10. Барабаш М.С. Компьютерное моделирование процессов жизненного цикла объектов строительства. - Киев: Сталь, 2014. - 301 с.

11. Кирьязев П., Гензерский Ю., Ромашкина М. Компьютерные модели узлов примыкания к диафрагме. // Проблеми розвитку міського середовища, 2014, Вип. 2, с. 236-246.

12. Перельмутер А.В., Сливкер В.И. Расчетные модели сооружений и 
Sixth Degree of Freedom

возможность их анализа. - Киев: Сталь, 2002. $-600 \mathrm{c}$.

Городецкий Александр Сергеевич - академик Российской академии архитектуры и строительных наук, доктор технических наук, профессор, заместитель директора по научной работе ООО «ЛИРА САПР», Украина, 04053 Киев, Кияновский переулок 7-а; тел.: +38 (050) 35196 61;

E-mail: info@liraland.com.ua, http:www.liraland.ru

Ромашкина Марина Андреевна - кандидат технических наук, инженер группы сопровождения ООО «ЛИРА САПР», Украина, 04053 Киев, Кияновский переулок 7-a, phone: +38 (095) 931-52-50; e-mail: romashkina.liraland@gmail.com,

http: www.liraland.ru

ORCID ID: 0000-0002-7158-4037

Писаревский Богдан Юрьевич - аспирант кафедры компьютерные технологии строительства, Национального авиационного университета, инженерпрограммист компании ООО «ЛИРА САПР», 04053 , Украина, Киев, пер. Кияновский, д.7-а , тел.: +38 (044) 5905885 ,

E-mail: mikst1234@gmail.com

ORCID ID: 0000-0002-1001-2879

Alexander S. Gorodetsky - Academician of Russian Academy of Architecture and Construction Sciences, DSc, Professor, Deputy Director for Science of «LIRA SAPR» Ltd, 7a, Kiyanovsky side street (pereulok), Kiev, 04053, Ukraine; phone: +38 (050) 3519661 ;

E-mail: info@liraland.com.ua, http: www.liraland.ru

Maryna A. Romashkina - PhD, Support Engineer of «LIRA SAPR» Ltd, 7a, Kiyanovsky side street (pereulok), Kiev, 04053, Ukraine; phone: +38 (095) 931-52-50;

E-mail: romashkina.liraland@gmail.com,

http: www.liraland.ru

ORCID ID: 0000-0002-7158-4037

Bogdan Y. Pysarevskiy - Postgraduate student; Department of Computer Technology Building, National Aviation University, software engineer «LIRA SAPR» Ltd, 7a, Kiyanovsky side street (pereulok), Kiev, 04053, Ukraine; phone +38 (044) 59058 85,

E-mail: mikst1234@gmail.com

ORCID ID: 0000-0002-1001-2879 